\title{
MANAGERIAL EFFECTIVENESS AND EFFICIENCY OF SBI IN HIMACHAL
} PRADESH

\author{
LATA DEVI ${ }^{1} *$ \\ ${ }^{* 1}$ Rabindra Nath Tagore Govt. College Sarkaghat Distt. Mandi Himachal Pradesh-India, E-mail: \\ dp_dental@rediffmail.com
}

Corresponding Author: -

E-mail:dp_dental@rediffmail.com

\begin{abstract}
: -
Managerial effectiveness varies from organization to organization and from job to job. The concept of managerial effectiveness is the central issue in management. Managerial effectiveness has to be defined in terms of output rather than input, by what a manager achieves rather than by what he does. Effectiveness is best seen as something a manager produces from a situation by managing it appropriately. It represents output, not input. The manager must think in terms of performance, not personality. It is not so much what a manager does, but what he achieves. The measure of effectiveness whether of an organization or individual is performance that is the attainment of the objective with a style. The study covers managerial effectiveness in SBI in Himachal Pradesh. The various indicators such as appraisal system, training techniques and facilities, career planning, organization development interventions has been considered and analyzed. The study has been analyzed by using simple mathematical tools and chi-square test.
\end{abstract}

Key Words: - Management, Managerial Effectiveness, Bank, Career Path

\section{(c) (\$) (1)}




\section{INTRODUCTION:}

Management is basically concerned with ideas, things and people. In fact there are various definitions of management but none has been universally accepted. Mary Parker Follett has suggested one simple definition which is very popular. According to her management is, "The art of getting things done through people."

Managerial effectiveness is the relationship between performance and task objectives and between achievements assessed against goals and purposes, within the constraints imposed by the manager himself, by his position in the organization and by the socio-economic environment. Managerial efficiency is the proportion of total organization resources that contribute to productivity during the manufacturing process. Effectiveness means that the job was done correctly and was accomplished but does not regard if the job was done inexpensively or on time. Whereas, efficiency means that the job was accomplished cheaply and on time yet may not be a very thorough and impressive accomplishment.

Peter Drucker ${ }^{1}$ in his book, The Effective Executive, draws a distinction between efficiency and effectiveness. He says; "Efficiency is doing things right; effectiveness is doing the right things." According to Bill Reddin ${ }^{2}$, the root to effectiveness is managerial style and situation. Pareek U. ${ }^{3}(1987)$ in his article "Motivating Organizational Roles: Roles Efficacy Approach "has proposed that motivating organizational roles depends on understanding, measuring and controlling the role attributes that can enhance individual contribution to organizational growth and effectiveness. He also maintained that several role processes can be examined with in managerial positions that tend to affect his operating effectiveness in organization. Lunthas, Welsh and Taylor $(1988)^{4}$ developed a model of managerial effectiveness which suggest that human resource management activities (such as staffing and motivating reinforcing) may help attain more output (quantity of performance) but more traditional management activities (such as planning, controlling and keeping in contact with outsiders such as supplies)may help in improving quality performance. Basu $(1988)^{5}$ found that in India majority of organization use personality traits and managerial skills for appraising performance as against organizations using performance only for appraising. It can be seen that personality traits and managerial skills are also important determinants of performance. Amsa.P. and Aithal, K.N. $(1989)^{6}$ in a study of regional managers in a commercial bank, found that more effective and less effective managers differed in terms of the degree to which they displayed communications behavior, participative behaviour, supportive behaviour and responsive behaviour. Manikutty S. (2005) in his paper argues that for effective development of managers training programs are far from sufficient. The major development of managerial capabilities in fact, takes place not so much as a result of training programs on the job. The development of junior managers by senior managers is a vital activity in a learning organization. Chauhan, S.P. and Chauhan, Daisy $(2007)^{8}$ conducted study to assess the impact of emotional intelligence on decision making and role efficacy of managers. The study revealed that managers at the top level had significant higher level of emotional intelligence and correspondingly they were high on decision making capacity. There is positive relation between emotional intelligence and role efficacy.

\section{Methodology:}

In the present study the branches of SBI in Himachal Pradesh has been covered. The sample size of 200 officers of different branches of Himachal Pradesh has been taken to cover the study. The sample consists of officers from all grades related on the basis of convenient sampling. The data was collected from the organization under study from primary as well as secondary sources. The primary data for the purpose was collected through questionnaire, interviews and observation. The primary data was supplemented by secondary data available from published reports, manuals, circulars, notifications and other circulars, notification and other literature related to topic under the study.

\section{Tools and Techniques}

Tools and techniques used keeping in view the nature of study; the data collected have been analyzed and interpreted with the help of following methods.

Mathematical methods: In the present study the data collected have been analyzed with the help of mathematical methods such as simple average and percentage method.

Chi Square Test: The non-parametric tests which have been used in this research is chi-square test. It has been used to examine the managerial effectiveness of officers in SBI of Himachal Pradesh. Chi-square test is a test which described the magnitude of difference between observed frequencies and frequencies expected under certain assumptions.

$$
x^{2}=\frac{\sum(o-E)^{2}}{E}
$$

Where, o refers to the observed frequencies, E refers to the expected frequencies, $x^{2}$ is symbol for chi-square test.

\section{Results and Discussions:}

Another question was asked about motivation for self-development to the respondent of State Bank of India to know whether self-appraisal motivates self-development. The data was further analyzed on the basis of age, educational qualification, work experience and place. 
Table 1: Perception of respondents that self-appraisal motivate self-development on the basis of age

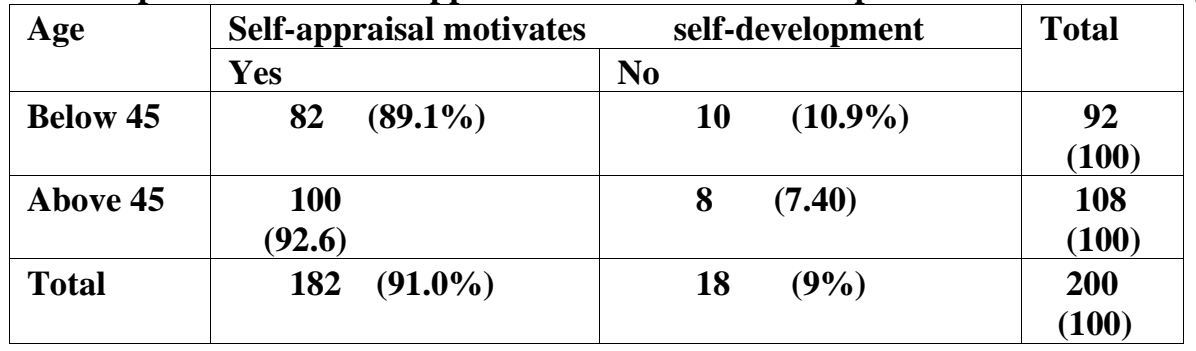

Table 1 depicts that respondent 100 (92.6\%) above the age of 45 are of the opinion that self-appraisal motivates selfdevelopment followed by the respondents below the age of 45, $82(89.1 \%)$. It shows that there is not much difference of opinion about the above perception.

While calculating the $x^{2}$ the value (11.910) is more than the table value at $5 \%$ level of significance. So, null hypothesis is rejected. So the difference is significant.

Table 2: Perception of respondents about self-appraisal motivate self-development, on the basis of educational qualification

\begin{tabular}{|c|c|c|c|}
\hline \multirow[t]{2}{*}{$\begin{array}{l}\text { Educational } \\
\text { Qualification }\end{array}$} & \multicolumn{2}{|c|}{$\begin{array}{l}\text { Self-appraisal motivates } \\
\text { development }\end{array}$} & \multirow[t]{2}{*}{ Total } \\
\hline & Yes & No & \\
\hline Graduate & $62 \quad(88.6 \%)$ & $\begin{array}{c}8 \\
(11.4 \%)\end{array}$ & $\begin{array}{c}\mathbf{7 0} \\
(\mathbf{1 0 0})\end{array}$ \\
\hline P.G. & $92 \quad(92.0 \%)$ & $\begin{array}{c}8 \\
(8.0 \%)\end{array}$ & $\begin{array}{r}100 \\
(100)\end{array}$ \\
\hline Professional & $28 \quad(93.3 \%)$ & $2 \quad(6.7 \%)$ & $30 \quad(100)$ \\
\hline Total & $182 \quad(91.0 \%)$ & $18 \quad(9 \%)$ & $\begin{array}{l}200 \\
(100)\end{array}$ \\
\hline
\end{tabular}

From the table it is very clear that respondents $93 \%$ having the professional qualification are agree that self-appraisal motivate self-development. Further $92 \%$ respondents having post graduate qualification and $88.6 \%$ graduate respondents are of the opinion that self-appraisal motivates self-development when the response of graduate is seen $(88.6 \%)$ have favour the above statement.

While applying the $x^{2}$ test its value (12.201) is higher than the table value at $5 \%$ level of significance. So, null hypothesis is rejected. So, it can be concluded that there is significant difference between the opinion of the respondents about the statement self-appraisal motivate self-development.

Table 3 Perception of respondents about self-appraisal motivate self-development, on the basis of work experience

\begin{tabular}{|c|c|c|c|}
\hline \multirow{2}{*}{$\begin{array}{c}\text { Work } \\
\text { Experience }\end{array}$} & \multicolumn{2}{|c|}{ Self appraisal motivate } & \multirow[t]{2}{*}{ Total } \\
\hline & Yes & No & \\
\hline Below $10 \quad$ Years & $36 \quad(97.7 \%)$ & $\begin{array}{c}2 \\
(5.3 \%)\end{array}$ & $\begin{array}{c}38 \\
(\mathbf{1 0 0})\end{array}$ \\
\hline 10-20 years & $50 \quad(86.2 \%)$ & $\begin{array}{c}8 \\
(13.8 \%)\end{array}$ & $58(100)$ \\
\hline Above 20 years & $96 \quad(92.3 \%)$ & $8 \quad(7.7 \%)$ & $\begin{array}{c}104 \\
(100)\end{array}$ \\
\hline Total & $182(91.0 \%)$ & $18 \quad(9 \%)$ & $\begin{array}{l}200 \\
(100)\end{array}$ \\
\hline
\end{tabular}

The table depicts that the respondents below the 10-year experience (94.7\%) are of the opinion that self-appraisal motivate self-development followed by the respondents (92.3\%) above than twenty-year work experience followed by $86.2 \%$ respondents with the experience 10-20 year. While applying $x^{2}$ test its value (14.549) is higher than table value at $5 \%$ level of significance. So out hypothesis is rejected. It means there is significant difference of opinion about self-appraisal motive self-development. 
Table 4 Perception of respondents about self-appraisal motivate self-development, on the basis of place of positing

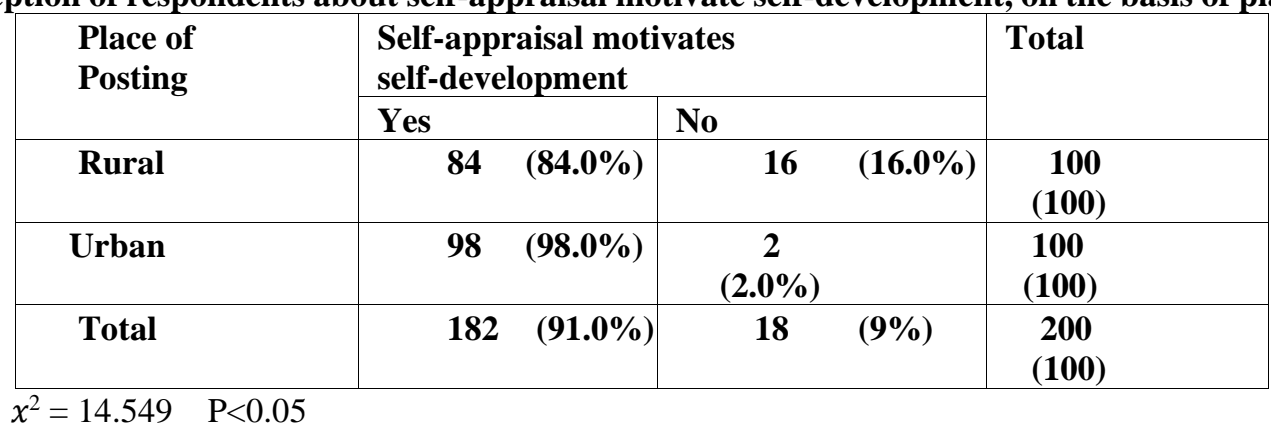

The table 4 depicts that the respondents $(98 \%)$ who are working in the urban area are in the favour that self-appraisal motivate self-development followed by $(84.0 \%)$ respondents are working in the rural area. From the above table it is very clear that there is not much difference of responses on the basis of place of posting may be in rural area or urban area. While applying the $x^{2}$ test its value (12.410) is higher than the table value at 5\% level of significance. So, null hypothesis is rejected and we can conclude that there is significant difference of opinion about self-appraisal motivate selfdevelopment.

\section{Awareness of Career Path}

A question was asked from the respondents of the SBI about awareness of career path in their bank and procedure of advancement in career. They were asked to reply yes/no. The data was further analyzed on the basis of age, educational qualification, work experience \& place of posting.

Table 5 Awareness about career path and procedure of advancement in career on the basis of age

\begin{tabular}{|c|c|c|c|}
\hline \multirow[t]{2}{*}{ Age } & \multicolumn{2}{|c|}{ Awareness of career path } & \multirow[t]{2}{*}{ Total } \\
\hline & Yes & No & \\
\hline Below 45 & $\begin{array}{r}82 \\
(89.1 \%)\end{array}$ & $\begin{array}{r}10 \\
(10.9 \%)\end{array}$ & $\begin{array}{c}92 \\
(\mathbf{1 0 0})\end{array}$ \\
\hline Above 45 & $\begin{array}{c}96 \\
(90.6 \%)\end{array}$ & $10 \quad(9.4 \%)$ & $\begin{array}{c}106 \\
(100)\end{array}$ \\
\hline Total & $\begin{array}{r}178 \\
(89.9 \%) \\
\end{array}$ & $\begin{array}{r}20 \\
(10.1 \%)\end{array}$ & $\begin{array}{c}198 \\
(100)\end{array}$ \\
\hline
\end{tabular}

It can be predicted from the table 5 that the respondents $96(90.6 \%)$ above the age of 45 are of the opinion that they are aware about career path in the bank and the procedure of advancement in career. On the other hand respondents 82 (89.1\%) also aware about career path in the bank and procedure of advancement in career.

While applying $x^{2}$ test its value (.112) is less than the table value. So out hypothesis is accepted means there is no significant difference of opinion about the awareness of career path in the bank and procedure of advancement in career on the basis of age.

Table 6 Awareness about career path procedure of advancement in career on the basis of educational qualification

\begin{tabular}{|c|c|c|c|}
\hline \multirow{2}{*}{$\begin{array}{l}\text { Educational } \\
\text { Qualification }\end{array}$} & \multicolumn{2}{|c|}{ Awareness of career path } & \multirow[t]{2}{*}{ Total } \\
\hline & Yes & No & \\
\hline Graduate & $\begin{array}{c}62 \\
(88.6 \%)\end{array}$ & $\begin{array}{c}8 \\
(11.4 \%)\end{array}$ & $\begin{array}{c}70 \\
(100)\end{array}$ \\
\hline P.G. & $\begin{array}{c}96 \\
(98.0 \%)\end{array}$ & $\begin{array}{c}2 \\
(2.0 \%)\end{array}$ & 98 (100) \\
\hline Professional & $\begin{array}{r}20 \\
(66.7 \%) \\
\end{array}$ & $10 \quad(33.3 \%)$ & $30 \quad(100)$ \\
\hline Total & $\begin{array}{r}178 \\
(89.9 \%)\end{array}$ & $20 \quad(10.1 \%)$ & $\begin{array}{r}198 \\
(100)\end{array}$ \\
\hline
\end{tabular}

Table 6 depicts that respondent (98\%), who are post graduate are aware of career path and procedure of advancement followed by graduate $(88.6 \%)$ and professional $(66.7 \%)$. Table further shows that the respondents who are post graduate are more aware. Although more difference is not seen in graduate, post graduate and professional respondents.

While applying $x^{2}$ test its value (24.979) is higher than the table value of significant. So, our hypothesis is rejected. So, it can be concluded that there is significant difference of opinion of respondents about awareness of career path and procedure of advancement in the bank on the basis of educational qualification. 
Table 7 Awareness about career path and procedure of advancement in career on the basis of work experience

\begin{tabular}{|c|c|c|c|}
\hline \multirow{2}{*}{\begin{tabular}{|c|} 
Work \\
Experience
\end{tabular}} & \multicolumn{2}{|c|}{ Awareness of career path } & \multirow[t]{2}{*}{ Total } \\
\hline & Yes & No & \\
\hline Below 10 & $34 \quad(89.5 \%)$ & $\begin{array}{c}4 \\
(10.5 \%)\end{array}$ & $\begin{array}{c}38 \\
(100)\end{array}$ \\
\hline $10-20$ years & $46 \quad(79.3 \%)$ & $12 \quad(20.7 \%)$ & $58(100)$ \\
\hline Above 20 years & $98 \quad(96.1 \%)$ & $4 \quad(3.9 \%)$ & $\begin{array}{c}102 \\
(100)\end{array}$ \\
\hline $\begin{array}{l}\text { Total } \\
x^{2}=11.45\end{array}$ & $178 \quad(89.9 \%)$ & $(10.1 \%)$ & $\begin{array}{c}198 \\
(100) \\
<0.05\end{array}$ \\
\hline
\end{tabular}

Table 7 depicts that respondents, 98(96.1\%) above the experience of 20 year are aware about the career path and procedure of advancement in career followed by respondents $34(89.5 \%)$ below the experience of ten year and respondents 46 (79.3\%) with the experience of 10-20 year. It can be predicated that there is no difference of opinion about the above statement in the basis of work experience.

While applying the $x^{2}$ test its value (11.458) is more than the table value at $5 \%$ level of significance. So our hypothesis is rejected. It shows that there is a significant difference in the opinion of the respondents with regard to awareness about career path and advancement in career on the basis of work experience

Table 8 Awareness about career path and procedure of advancement in career on the basis of place of posting

\begin{tabular}{|c|c|c|c|}
\hline \multirow[t]{2}{*}{ Place of Posting } & \multicolumn{2}{|c|}{ Awareness of career path } & \multirow[t]{2}{*}{ Total } \\
\hline & Yes & & \\
\hline Rural & $\begin{array}{l}88 \\
(89.8 \%)\end{array}$ & $\begin{array}{l}10 \\
(10.2 \%)\end{array}$ & $\begin{array}{l}98 \\
(100)\end{array}$ \\
\hline Urban & $\begin{array}{l}90 \\
(90.0 \%)\end{array}$ & $\begin{array}{l}10 \\
(10.0 \%)\end{array}$ & $\begin{array}{l}100 \\
(100)\end{array}$ \\
\hline Total & $\begin{array}{l}178 \\
(89.9 \%)\end{array}$ & $\begin{array}{l}20 \\
(10.1 \%)\end{array}$ & $\begin{array}{l}198 \\
(100)\end{array}$ \\
\hline
\end{tabular}

It can be predicated from the table 8 that the respondents 90 (90.0\%) working in urban area are aware about career path in the bank and procedure of advancement in career followed by respondents $88(89.8 \%)$ working in rural area. It is clear from the above table that there is no difference of opinions of the respondents on the basis of place of posting. Most of the respondents may posted in urban or rural areas are aware of career path.

While applying $\boldsymbol{x}^{2}$ test its value (0.02) is less than the table value. So, our hypothesis is accepted. So, there is no significant difference of the respondent on the basis of place of posting about the awareness of career path in the bank and procedure of advancement in career as also predicted on the basis of percentage.

\section{Existing Career Path Opportunities}

In the course of survey, a question was asked about the existing career opportunities from the respondents. Respondents were asked to give rating to this question on the basis of good, average or poor. The collected data was further classified on the basis of age, educational qualification, work experience and place of posting.

Table 9 Perception of respondents about existing career path opportunities in the bank of the basis of age

\begin{tabular}{|c|c|c|c|c|}
\hline \multirow[t]{2}{*}{ Age } & \multicolumn{3}{|c|}{ Career path opportunities } & \multirow[t]{2}{*}{ Total } \\
\hline & Good & Average & Poor & \\
\hline Below 45 & $\begin{array}{c}76 \\
(82.6 \%)\end{array}$ & $\begin{array}{c}16 \\
(17.4 \%)\end{array}$ & $\begin{array}{c}0 \\
(0.0 \%)\end{array}$ & $\begin{array}{c}92 \\
(100)\end{array}$ \\
\hline Above 45 & $\begin{array}{c}78 \\
(72.2 \%)\end{array}$ & $\begin{array}{c}28 \\
(25.9 \%)\end{array}$ & $\begin{array}{c}2 \\
(1.9 \%)\end{array}$ & $\begin{array}{c}108 \\
(100)\end{array}$ \\
\hline Total & $\begin{array}{c}154 \\
(77.0 \%)\end{array}$ & $\begin{array}{c}44 \\
(22.0 \%)\end{array}$ & $2(1.0)$ & $\begin{array}{c}200 \\
(\mathbf{1 0 0})\end{array}$ \\
\hline
\end{tabular}

Table 9 manifests that 76 respondents out of 92 of age of below 45 i.e. $82.6 \%$ and respondents 78 out of 108 of the age of above 45 i.e. $72.2 \%$ have given rating as good to existing career path opportunities. On the other hand respondents 28 $(25.9 \%)$ out of 108 above the age of 45 and respondents $16(17.4 \%)$ below the age of 45 rate it as average. While applying $x^{2}$ test its value (4.045) is less than table value at $5 \%$ level of significant difference in opinion in rating if existing career path opportunities in the bank on the basis of age. 
Table 10 Perception of respondents about existing career path opportunities in the bank on the basis of educational qualification

\begin{tabular}{|c|c|c|c|c|}
\hline \multirow{2}{*}{$\begin{array}{l}\text { Educational } \\
\text { Qualification }\end{array}$} & \multicolumn{3}{|c|}{ Career path opportunities } & \multirow[t]{2}{*}{ Total } \\
\hline & Good & Average & Poor & \\
\hline Graduate & $\begin{array}{c}56 \\
(80.0 \%)\end{array}$ & $\begin{array}{c}14 \\
(20.0 \%)\end{array}$ & $\begin{array}{c}0 \\
(0.0 \%)\end{array}$ & $\begin{array}{c}\mathbf{7 0} \\
(\mathbf{1 0 0})\end{array}$ \\
\hline P.G. & $\begin{array}{c}72 \\
(72.0 \%) \\
\end{array}$ & $\begin{array}{c}28 \\
(28.0 \%)\end{array}$ & $\begin{array}{c}0 \\
(0.0 \%)\end{array}$ & $\begin{array}{c}100 \\
(100)\end{array}$ \\
\hline Professional & $\begin{array}{c}26 \\
(86.5 \%)\end{array}$ & $\begin{array}{c}2 \\
(6.7 \%)\end{array}$ & $\begin{array}{c}2 \\
(6.7 \%)\end{array}$ & $30 \quad(100)$ \\
\hline Total & $\begin{array}{c}154 \\
(77.0 \%)\end{array}$ & $\begin{array}{c}44 \\
(22.0 \%)\end{array}$ & $\begin{array}{c}2 \\
(1.0 \%)\end{array}$ & $\begin{array}{c}200 \\
(100)\end{array}$ \\
\hline
\end{tabular}

Table 10 manifests that respondents $26(86.7 \%)$ out of 30 with the professional qualification have given the rating as good to the existing career path opportunities in the bank followed by the respondents $72(72.0 \%)$ out of 100 with the post graduate qualification and respondent $56(80 \%)$ out of 70 respondents. While applying the $x^{2}$ test its value (17.074) is higher than the table value at $5 \%$ level if significance. So, our hypothesis is rejected, which indicate that there is a significant difference in the opinion of the respondents with regard to existing career path opportunities on the basis of educational qualification.

Table 11 Perception of respondents about existing career path opportunities in the bank on the basis of work experience

\begin{tabular}{|c|c|c|c|c|}
\hline \multirow{2}{*}{$\begin{array}{l}\text { Work } \\
\text { Experience }\end{array}$} & \multicolumn{3}{|c|}{ Career path opportunities } & \multirow[t]{2}{*}{ Total } \\
\hline & Good & Average & Poor & \\
\hline $\begin{array}{r}\text { Below } 10 \\
\text { Years }\end{array}$ & $\begin{array}{c}30 \\
(78.9 \%)\end{array}$ & $\begin{array}{c}8 \\
(20.0 \%)\end{array}$ & $\begin{array}{c}\mathbf{0} \\
(\mathbf{0 . 0 \%})\end{array}$ & $\begin{array}{c}38 \\
(100)\end{array}$ \\
\hline $10-20$ years & $\begin{array}{c}50 \\
(86.2 \%) \\
\end{array}$ & $\begin{array}{c}6 \\
(10.3 \%) \\
\end{array}$ & $2(3.4 \%)$ & 58 (100) \\
\hline $\begin{array}{c}\text { Above } 20 \\
\text { years }\end{array}$ & $\begin{array}{c}74 \\
(71.2 \%)\end{array}$ & $\begin{array}{c}30 \\
(28.8 \%)\end{array}$ & $\begin{array}{r}0 \\
(0 \%)\end{array}$ & $\begin{array}{r}104 \\
(100)\end{array}$ \\
\hline Total & $\begin{array}{c}154 \\
(77.0 \%)\end{array}$ & $\begin{array}{c}44 \\
(22.0 \%)\end{array}$ & $\begin{array}{c}2 \\
(1.0 \%)\end{array}$ & $\begin{array}{c}200 \\
(100)\end{array}$ \\
\hline
\end{tabular}

Table 11 shows that respondents $50(86.2 \%)$ out of 58 with the experience of 10-20 year, $30(78.9 \%)$ respondents out of total 38 with the experience of below 10 years and respondents $74(71.2 \%)$ out of total 104 have rated as good to existing career path opportunities in the bank. On the other hand the respondents above 20 years experience with the percentage $28.8 \%$ respondents with the experience of 10 years. $21 \%$ and respondents with the experience of $10-20$ years i.e. $10.3 \%$ have rated average to existing career path opportunities. While applying the $x^{2}$ test its value (11.828) in more than the table value at $5 \%$ level of significance. So, null hypothesis is rejected. It means there is significance difference of opinion of respondents on the basis of work experience about rating of existing career path opportunities on the basis of work experience.

Table 12 Perception of respondents about existing career path opportunities in the bank on the basis of place of posting

\begin{tabular}{|c|c|c|c|c|}
\hline $\begin{array}{c}\text { Place } \\
\text { Posting }\end{array}$ & of & Career path opportunities & Total \\
\cline { 2 - 5 } Rural & Good & Average & Poor & \\
\hline Urban & $\mathbf{7 8}$ & $\mathbf{2 2}$ & $\mathbf{0}$ & $\mathbf{1 0 0}$ \\
& $(\mathbf{7 8 . 0 \%})$ & $(\mathbf{2 2 . 0 \% )}$ & $(\mathbf{0 . 0 \%})$ & $(\mathbf{1 0 0 )}$ \\
\hline Total & $\mathbf{7 6}$ & $\mathbf{2 2}$ & $\mathbf{2}$ & $\mathbf{1 0 0}$ \\
& $(\mathbf{7 6 . 0 \%})$ & $(\mathbf{2 2 . 0 \%})$ & $\mathbf{( 2 . 0 \% )}$ & $\mathbf{( 1 0 0 )}$ \\
\hline$x^{2}=11.828$ & $\mathbf{1 5 4}$ & $\mathbf{4 4}$ & $\mathbf{2}$ & $\mathbf{2 0 0}$ \\
& $(\mathbf{7 7 . 0 \% )}$ & $(\mathbf{2 2 . 0 \%})$ & $(\mathbf{1 . 0 \%})$ & $\mathbf{( 1 0 0 )}$ \\
\hline
\end{tabular}

From the table 12 is very clear that there is no difference of opinion due to place of posting about rating of existing career path opportunities because it is $78 \%$ in the case of rural respondent and $76 \%$ in the case of urban respondent. While comparing average rating there is no difference of rating as percentage because it is $22 \%$ for rural as well as urban respondent. 
While applying the $x^{2}$ test its value (2.026) in less than the table value at $5 \%$ level of significance. So, our hypothesis is accepted. It means that there is no statistical difference of opinion on the basis of place of posting of the respondents about career path opportunities in the bank.

\section{Conclusion:}

From the study it has been found that the majority of managers agreed that self-appraisal motivates the self-development. Self-development is more in professional managers. With the increase in age \& work experience the job satisfaction level of managers is also increasing. They are ready to work both in rural and urban areas. The managers prefer performancebased appraisal rather than trait based. The managers are fully aware of their career path. There is not so much difference in awareness but the managers having post-graduation are more aware.

Placement decisions are taken on the basis of top management requirement.

\section{References:}

[1].Drucker F.P., (1967) The effective executive: the definitive guide to getting the right things done Recorded Books, Inc.

[2].Reddin W.J., (1987) Effective Management, Tata McGrawHill, 6.

[3].Pareek U., (1987) Motivating Organizational Roles: Role Efficacy Approach, Jaipur: Rawat Publications.

[4].Luthans F, Welsh D.H.B, and Taylor, L., (1988) A descriptive model of managerial effectiveness. Group and Organization Studies 13(2): 148-162.

[5].Basu S., (2000) Health and Population - Perspectives and Issues. Dimensions of Tribal Health in India 23(2): 61-70.

[6].Amsa P. and Aithal K.N., (1989) Effectiveness and Leadership Behavior of Regional Managers in a Public sector Bank : An Empirical study. Decision Journal 16 (2): 137 - 149.

[7].Manikutty S., (2005) Manager as a Trainer, a Coach, and a Mentor. VIKALPA 30(2): 57-64.

[8].Chauhan S.P. and Chauhan D., (2007) Emotional Intelligence: Does It Influence Decision Making and Role Efficacy? Indian Journal of Industrial Relations 43(2): 217-238. 